\section{WORK OF THE IMPERIAL INSTITUTE}

\author{
By Sir HarRy Lindsay, K.C.I.E., C.B.E., \\ DIRECTOR, IMPERIAL INSTITUTE
}

$\mathrm{D}^{\mathrm{n}}$ R. COLLINGE'S account, published in NATURE of October 19, p. 526, of the work of the Philadelphia Museum shows that it follows lines closely analogous to those adopted by the Imperial Institute in the display of raw materials (in our case, of the British Empire) and the 'story' of their transformation to finished goods. The Institute is also a bureau of technical information based not only on investigations carried out in our own laboratories but also on information available from technical and trade journals in all languages.

Unfortunately, our exhibition galleries and cinema have had to be closed under war conditions. We still continue, however, to send films of the Empire on loan to schools and societies throughout the United Kingdom. In place of our series of lectures on the overseas Empire, which used to attract many hundreds of school parties to our cinema, we have adopted a scheme whereby a panel of Empire lecturers is made available to primary and secondary schools in reception areas. Our latest development is to try to transfer, with the help of our artists, the 'story' of the transformation of raw materials into finished commodities from showcases in our galleries to posters which will be made available to schools together with lecture notes to accompany them.

With regard to our technical intelligence bureau, the Institute's staff includes tropical agriculturists, chemists, chemical technologists, economic botanists, economic geologists, mining engineers, mineralogists and statisticians, all of whom are expert in their particular subjects. When desirable, the Institute seeks the advice of members of its fifteen consultative committees, which comprise authoritative professional and business men. Further help is also afforded by numerous trade contacts.

The Institute also has an extensive reference library and a technical index covering most of the relevant trade and scientific publications issued during the past thirty years.

Examples of the type of inquiry dealt with at the Institute include the following: Inquiries relating to sources of supply of raw materials and semi-manufactured products whether of animal, vegetable or mineral origin in all countries; inquiries relating to the marketing of overseas products; detailed statisties of production, consumption and trade in all countries; questions concerning the normal uses of all raw materials and most semi-manufactured products and discussions concerning possible new or alternative uses; inquiries concerning the specifications as to qualities and types of raw materials necessary for various purposes; questions arising out of a desire to substitute one commodity for another; details of the methods employed in the cultivation of crops and the soil and conditions under which they have to be grown; details of the methods employed in mining, smelting and dressing minerals for the market ; methods of processing and preparation for the market of animal and vegetable products, and particulars of machinery and equipment used for these purposes; details of the location and plant capacity of works at which smelting or refining or other processing is carried out; analysis and testing of samples of raw materials in the laboratories of the Institute.

\section{FORTHCOMING EVENTS}

\author{
Monday, November II
}

Royal Geographical Society (at Kensington Gore, London, S.W.7), at 3 p.m.-Dr. Dudley Stamp: "Productivity and Classification of Land in Britain".

Wednesday, November I3

Royal Society of Arts (at John Adam Street, Adelphi, London, W.C.2), at 1.45 p.m.-Dr. K. G. Fenelon: "Some Problems of Wartime Labour Management."

\section{Thursday, November 14}

Pharmaceutical Society (at 17 Bloomsbury Square, London, W.C.1), at 2.30 p.m.-Prof. A. Fleming: "Antisepties in Wartime Surgery".

\section{Friday, November 15}

North-East CoAst Institution of Engineers and SHIPBUILDERS (in the Mining Institute, Newcastleupon-Tyne), at 6 p.m.-Dr. G. S. Baker: "Vibration Patterns of Propeller Blades".

\section{APPOINTMENTS VACANT}

Appurcatrons are invited for the following appointments on or before the dates mentioned :

Two Graduates in EngINEFRING at the Ipswich School of Engineering-The Secretary for Education, Tower House, Ipswich (November 13).

HEAD OF THE Electrical ENgINEERING DEPARTMENT at the Chesterfleld Technical College-The Clerk to the Governors, Technica College, Inflrmary Road, Chesterfleld (November 16).

Headmaster of THe Shipley ART School and Headmasthr of THE SHIPLEY TECHNIOAI INSTITUTE (combined appointment)-The Secretary to the Managers, West Riding County Council, Town Hall Shipley (November 20).

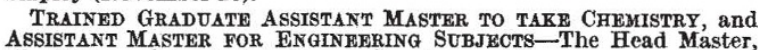
The Modern School, Cole Street, Scunthorpe, Lincs.

\section{REPORTS AND OTHER PUBLICATIONS \\ (not included in the monthly Books Supplement)}

\section{Great Britain and Ireland} East African Agricultural Research Station, Amani. Annual
Report, 1939. (Colonial No. 180.) Pp. 26. (London: $\mathbf{H} . \mathbf{M}$. Stationery Report, 1939. (Colonial No. 180.) Pp. 26. (London: H.M. Stationery
[2210

Wool Industries Research Association. Animal Fibres of Industrial Importance : their Origin and Identification. By A. B. Wildman. Pp. $28+23$ plates. (Leeds: Wool Industries Research Association.) [2310

\section{Other Countries}

Indian Forest Records (New Series). Silviculture, Vol. 3, No. 8 : A Note on the Artiflcial Regeneration of the Dry Fuel Forests of the Madras Province. By A. L. Griffith. Pp. vii +291-322. (Delhi : Manager of Publications ) 1.14 rupees ; $28.9 d$.

Indian Association for the Cultivation of Science. Annual Report for the Year 1939. Pp. 44. (Calcutta: Indian Association for the for the Year 1939. Pp. 44. (Calcutta: Indian Association for the
Cultivation of Science.)

U.S. Department of Agriculture. Miscellaneous Publication No. 354: A Review of the Parasitic Wasps of the Ichneumonid Genus Exenterus Hartig. By R. A. Cushman. Pp. 15. (Washington, D.C. Government Printing Office.) 5 cents.

Proceedings of the American Academy of Arts and Sciences. Vol. 73, No. 13: Four Hundred Word Chin Tan of Chang Po-Tuan Three Alchemical Poems by Chang Po-Tuan; Shih Hsing-Lin, Disciple of Chang Po-Tuan and Hsieh Tao-Kuang, Disciple of Shih Hsing-Lin The Secret Papers in the Jade Box of Ch'ing-Hua, and A Fifteenth Century Chinese Encyelopedia of Alchemy. By Tennend A Fifteenth Chao Yun-ts'ung. Pp. 371-400. 1 dollar. Vol. 73, No. 14: Gyromagnetic Ratios for Ferromate 1 dollar. Vol. 73, No. 14 : Gyroand a New Discussion of Earlier Determinations. By S. J. Barnett. Pp. 401-456. 1.75 dollars. (Boston: American Academy of Brnett Sciences.)

$[1510$

Canada : Department of Mines and Resources, Mines and Geology Branch: Bureau of Mines. Talc, Steatite and Soapstone; Pyrophyllite. By Hugh S. Spence. (No. 803.) Pp. vii $146+8$ plates. 